\title{
Relationships among plant genetics, phytochemistry and herbivory patterns in Quercus castanea across a fragmented landscape
}

Received: 9 March 2014/ Accepted: 15 November 2014/Published online: 29 November 2014 (C) The Ecological Society of Japan 2014

\begin{abstract}
Herbivorous insects respond to the chemical variation of their host plants which, in turn, usually has a genetic component. Therefore, it is expected that individual host plants with similar genotypes will have similar secondary chemistries and herbivore communities. However, natural or anthropogenic environmental variation can also influence secondary chemistry and herbivore abundance and composition. Here, we determined the relationships among plant genetics, phytochemistry, and herbivory levels by leaf chewers and miners in the red oak Quercus castanea, across a fragmented landscape. Ten oak individuals were sampled at each of four sites in the Cuitzeo basin, central Mexico. Two sites were small and fragmented forest patches and two were large and continuous patches. Individuals were genotyped with six nuclear microsatellites, and analyzed chemically to determine foliar concentrations of water, total nonstructural carbohydrates, and secondary compounds. Damage by leaf chewers was higher in the small fragments than in the large fragments. Mantel tests indicated significant correlations of the genetic distance among individuals with their chemical similitude, and also of chemical similitude with damage levels by leaf miners, but not with damage by folivores. There was no direct relationship between genetic distance and herbivory levels by any of the two insect guilds. Our results suggest that variation in concentration of secondary metabolites in $Q$. castanea has a genetic component and that plant chemistry acts as an intermediate link between
\end{abstract}

Y. Maldonado-López · A. González-Rodríguez $(\bowtie) \cdot$ K. Oyama Centro de Investigaciones en Ecosistemas, Universidad Nacional Autónoma de México, Antigua Carretera a Pátzcuaro No. 8701, Col. Ex-Hacienda de San José de la Huerta, Morelia 58190 Michoacán, México

E-mail: agrodrig@cieco.unam.mx

Tel.: + 524433223831

Fax: +524433222719

P. Cuevas-Reyes · G. Pérez-López · C. Acosta-Gómez Laboratorio de Ecología de Interacciones Bióticas, Facultad de Biología, Universidad Michoacana de San Nicolás de Hidalgo, Ciudad Universitaria, Morelia 58030 Michoacán, México plant genes and the community of associated herbivores. However, this effect was only apparent for herbivory by leaf miners, probably because these insects interact more intimately with the host, while free-living leaf chewers may be more responsive to environmental variation.

Keywords Folivores ' Leaf miners ' Mexico ·

Microsatellites $\cdot$ Oak

\section{Introduction}

Plant genetics can influence the community structure of a wide range of associated organisms from microbes to vertebrates (Whitham et al. 2003; Bailey et al. 2006). In both agricultural and natural systems (Fritz and Price 1988; Anderson et al. 1989; Via 1990; Fritz and Simms 1992), genetic variation of host plants has an important role in regulating herbivore populations. Some studies indicate that insect herbivores not only distinguish between parental host plant species and their hybrids (Whitham 1989; Boecklen and Spellenberg 1990; Fritz et al. 1994), but also among different plant genotypes within a single species (Fritz and Price 1988; Maddox and Root 1990; Cronin and Abrahamson 2001; Wimp et al. 2005; Donaldson and Lindroth 2007). This discrimination among host plants can subsequently affect the community structure and arthropod diversity. Recent studies have shown that host-plant genotypic diversity can be related with species richness and abundance of the arthropod community (Wimp et al. 2004; Reusch et al. 2005; Crutsinger et al. 2006; Johnson et al. 2006; Tovar-Sánchez and Oyama 2006; Tovar-Sánchez et al. 2013). The variation in plant genotypic diversity can result in differences in both the average and the variance of plant quality among populations, producing a dissimilarity of susceptibility to particular insect herbivores (McCrea and Abrahamson 1987; Karban 1992; Hwang and Lindroth 1997; Hughes et al. 2008). Furthermore, interactions among different plant genotypes within populations can mod- 
ify individual quality levels (Hambäck et al. 2000; Hughes et al. 2008).

A potential mechanism involved in the relationship between plant genetics and arthropod community structure is the plant secondary chemistry composition (Maddox and Root 1990; Whitham et al. 1999; Dungey et al. 2000; Abrahamson et al. 2003; Hochwender and Fritz 2004; Wimp et al. 2004, 2005; Bangert et al. 2006). Similar plant genotypes usually have similar secondary chemistries and arthropod communities (Bangert et al. 2006). However, only a few studies have investigated the overall link among plant genetics, secondary chemistry and arthropod community structure (Johnson and Agrawal 2005; Bangert et al. 2006; Barbour et al. 2009).

Habitat fragmentation subdivides forests into "islands" or "fragments" surrounded by a matrix of environments altered by humans, decreasing the areas available to natural communities (Templeton et al. 1990). Therefore, habitat fragmentation causes changes in the genetic diversity and connectivity of populations (Cunningham and Moritz 1998; Gerlach and Musolf 2000; Aguilar et al. 2008; Herrera-Arroyo et al. 2013), and negatively affects species richness of plants and insects (Wettstein and Schmid 1999; Floren and Linsenmair 2001; Foggo et al. 2001) and alters population abundance and distribution (Hinsley et al. 1995; Fahring 2003; Sodhi et al. 2009). In addition, the structure and composition of insect communities associated with specific hosts is also affected (Chust et al. 2007). Therefore, habitat fragmentation may destabilize and collapse biotic interactions (Tscharntke and Brandl 2004; Valladares et al. 2006; Vásquez et al. 2007), specially reducing both the number of specialist insect species (Gibbs and Stanton 2001; Steffan-Dewenter et al. 2002), and the quantity and quality of resources for insect herbivores (Arnold and Asquith 2002; Kolb 2008). However, an important issue that remains to be addressed is whether some of these effects of fragmentation on biotic interactions are caused directly by environmental changes, or mediated indirectly by the modifications of host genetics that result from fragmentation.

The oaks (genus Quercus) are dominant species in temperate forests in Mexico and perform significant ecological functions such as nutrient cycling, water balance and biodiversity sustain (Nixon 1993). Also, oaks have a great economic importance, but unfortunately inadequate management has predominated with high deforestation and fragmentation rates in Mexico (Bello and Labat 1987; Bocco et al. 2001; ValenciaÁvalos and Nixon 2004; Arredondo-León et al. 2008).

Leaves of the genus Quercus are high in phenolic compounds (Schultz and Baldwin 1982; Faeth and Bultman 1986; Rossiter et al. 1988) and have played an important role in the development of the theory of plant defense against herbivores (e.g. Schultz and Baldwin 1982; Rossiter et al. 1988). Specifically, it has been shown in numerous experiments that tannins act as a broad-spectrum defense mechanism against herbivores, and are responsible for regulating herbivory levels
(Hunter and Schultz 1995; Erickson et al. 2004; Forkner et al. 2004).

In this study, we evaluated the relationships among plant genetics, chemical compounds and herbivory patterns by folivores and leaf miners associated with the Mexican red oak Quercus castanea in a fragmented landscape. In particular, we addressed the following questions: (1) is there an effect of habitat fragmentation on phytochemistry, herbivory levels and genetic diversity? (2) is there a relationship between herbivory patterns by different insect guilds, phytochemistry, and host plant genotypes?

\section{Methods}

\section{Study system}

Quercus castanea Née is a red oak (section Lobatae) (Nixon 1993) that grows as a moderately large tree $10-18 \mathrm{~m}$ in height, and $30-100 \mathrm{~cm}$ in diameter. Mature leaves are rigid and coriaceous, mostly oblanceolate and oblong-elliptic-lanceolate, with margins flat or slightly revolute, with teeth in the distal third of the blade, the upper surface hard, lustrous, gray-green, and the lower surface thinly gray-tomentose or yellowish. The flowering period is from April to May and acorns mature between July and November. These are nearly sessile, broadly ovoid (Valencia 1995). The species is often localized in association with tropical dry forests, in oak forests and in pine-oak forests, at altitudes between 1100 and $2600 \mathrm{~m}$. Q. castanea is one of the most widely distributed species within the red oak group in Mexico. It occurs in the Sierra Madre Oriental, Sierra Madre Occidental, Central Plateau, Trans-Mexican Volcanic Belt, Balsas Depression and Sierra Madre del Sur.

\section{Study site}

This study was conducted within the catchment basin of Lake Cuitzeo, with an area of $4026 \mathrm{~km}^{2}$. It is located in the north of the state of Michoacán, Mexico, between $19^{\circ} 30^{\prime}$ and $20^{\circ} 05^{\prime}$ latitude north and $100^{\circ} 35^{\prime}$ and $101^{\circ}$ $30^{\prime}$ longitude west, and an average altitude of $2000 \mathrm{~m}$. It is part of the Trans-Mexican Volcanic Belt morphotectonic province (Ferrusquía-Villafranca 1993). The climate is temperate with an average annual temperature of $17{ }^{\circ} \mathrm{C}$ and annual rainfall of about $800 \mathrm{~mm}$ concentrated in the summer. The lake of Cuitzeo is the second largest in Mexico (a wetland of about $300 \mathrm{~km}^{2}$ ). The basin is representative of the environmental and socioeconomic conditions of central Mexico and has experienced strong fragmentation of natural vegetation in the last decades (López et al. 2006; Mendoza et al. 2011). Around $20 \%$ of the basin is covered by temperate pineoak forests, the subtropical underbrush occupies about $15 \%$, induced grasslands less than $15 \%$, and crops 
occupy about $40 \%$ of the basin (López et al. 2006; Mendoza et al. 2011).

\section{Sampling design}

To select the study sites we used a database from previous analyses of land covers and recent land-use changes in the Cuitzeo basin (López et al. 2006; Mendoza et al. 2011). On the basis of this information we selected four sites that differ in forest condition, two small and fragmented forest patches $(<4$ ha): San Miguel del Monte (SMM, 19 $37^{\prime} 0^{\prime \prime} \mathrm{N} ; 101^{\circ} 7^{\prime} 42^{\prime \prime} \mathrm{W}$ ) and Santiago Undameo (SAU, $19^{\circ} 36^{\prime} 0^{\prime \prime} \mathrm{N} ; 101^{\circ} 16^{\prime}$ $52^{\prime \prime} \mathrm{W}$ ), and two large and continuous forest patches (>12 ha): Umécuaro (UME, 19 $31^{\prime} 39^{\prime \prime} \mathrm{N} ; 101^{\circ} 15^{\prime} 19^{\prime \prime}$ $\mathrm{W}$ ) and Cuanajo (CUA, $19^{\circ} 29^{\prime} 06^{\prime \prime} \mathrm{N}$; 101 $30^{\circ} 26^{\prime \prime} \mathrm{W}$ ). Otherwise, the sites were relatively proximate (the distance among patches was between 16 and $42 \mathrm{~km}$ ) and were similar in species composition (i.e. oak forest dominated by $Q$. castanea) and in elevation (2000-2300 m) and climatic conditions $\left(15-17^{\circ} \mathrm{C}\right.$ mean annual temperature, $900-1000 \mathrm{~mm}$ annual precipitation).

\section{Herbivory patterns by folivores and leaf miners}

In order to estimate the herbivory patterns by the two different insect guilds, we sampled 10 randomly chosen but spatially separated (at least $20 \mathrm{~m}$ ) adult trees of $Q$. castanea at each of the four sites. We used a stratified sampling within each tree, collecting three branches at each canopy stratum (lower, medium and high). From each branch 10-20 leaves were randomly selected, to a total of 50 leaves per canopy strata, 150 leaves per individual and 1500 leaves per site. The stem diameter at breast height (DBH) was measured for each tree sampled; all trees had $\mathrm{dbh} \geq 20 \mathrm{~cm}$. The leaf area removed by folivores and leaf miners was estimated using the 150 leaves per individual tree. A digital image of each leaf was obtained, and then the total leaf area and the leaf area removed by insects were estimated using the Sigma Scan Pro software.

\section{Genetic analyses}

Genomic DNA was extracted from $100 \mathrm{mg}$ of leaf material using the method proposed by Lefort and Douglas (1999). Six nuclear microsatellite loci (0C11, 0A01, 0C19, 1C08, 2M04, 1F07) previously designed for Quercus rubra (Aldrich et al. 2002) were selected based on the quality of preliminary amplification trials. All primers were multiplexed in single PCR reactions using the QIAGEN Multiplex PCR kit (QIAGEN). The final volume of each reaction was $5 \mu \mathrm{L}$, containing $1 \mathrm{X}$ Multiplex PCR Master Mix, $2 \mathrm{mM}$ each primer, deionized water, and $20 \mathrm{ng}$ DNA. The thermal cycling program was run on an Applied Biosystems thermocycler. The program consisted of one cycle at $95{ }^{\circ} \mathrm{C}$ for $15 \mathrm{~min}$ and then 35 cycles, each with denaturation at $95{ }^{\circ} \mathrm{C}$ for $30 \mathrm{~s}$, annealing at $55^{\circ} \mathrm{C}$ for $90 \mathrm{~s}$, and extension at $72{ }^{\circ} \mathrm{C}$ for $60 \mathrm{~s}$. A final extension at $60{ }^{\circ} \mathrm{C}$ for 30 min was included. Multiplex PCR products were diluted 1:1 in deionized water and run in an ABI-PRISM 3100-Avant sequencer with the GeneScan-500 LIZ size standard included (Applied Biosystems). DNA fragment final sizing was performed using Peak Scanner software, version 1.0 (Applied Biosystems).

\section{Chemical analysis}

Thirty intact leaves were collected from each individual tree and immediately stored in liquid nitrogen for chemical analyses. As indicators of nutritional quality, we measured water content and total nonstructural carbohydrates (Marquis et al. 1997). For water content, $2 \mathrm{gm}$ of fresh sample were weighted in an analytical balance and then placed in an oven at $105^{\circ} \mathrm{C}$. The samples were dried to a constant weight and allowed to cool for weight register. Water content was calculated as (fresh weight-dry weight/fresh weight). To determine the amount of total nonstructural carbohydrates (TNC) we performed the phenol-sulphuric method for TNC extraction from plant tissues (Marquis et al. 1997). Soluble sugars concentration was determined colorimetrically with an UV-visible spectrophotometer (EZ301 UV/VIS Spectrometer, Perkin-Elmer).

The total content of soluble phenolics was estimated using a modification of the Folin-Ciocalteau method (Torres et al. 1987), extracting the samples with $80 \%$ ethanol. One $\mathrm{ml}$ supernatant of the centrifuged sample was mixed with $0.5 \mathrm{ml} 2 \mathrm{~N}$ Folin-Ciocalteau's phenol reagent, and then $1 \mathrm{ml}$ of $20 \% \mathrm{Na}_{2} \mathrm{CO}_{3}$ was added. After $30 \mathrm{~min}$ of incubation at room temperature, the absorbance was measured at $730 \mathrm{~nm}$ on an UV-visible spectrophotometer. The standard curve was created with known concentrations of tannic acid. In the case of flavonoids, the samples were extracted with $80 \%$ ethanol. $0.1 \mathrm{ml}$ of supernatant was diluted in $0.9 \mathrm{ml} 80 \%$ ethanol. A $0.5 \mathrm{ml}$ aliquot was placed in a tube, and $0.3 \mathrm{ml} \mathrm{NaNO}_{2}$ (1:20) were added. After $5 \mathrm{~min}, 3 \mathrm{ml}$ $\mathrm{AlCl}_{3}$ (1:10) was added. Six min later, the solution was mixed and the absorbance was measured at $510 \mathrm{~nm}$ (Zhuang et al. 1992). The content of total flavonoids was calculated from a standard curve of quercitin.

For tannin quantification samples were extracted with $70 \%$ aqueous acetone, allowed to stand for $1 \mathrm{~h}$ at room temperature with continuous stirring and centrifuged for $10 \mathrm{~min}$ at $3000 \mathrm{rpm}$. The acetone extract was reduced to the aqueous phase, and then frozen and lyophilized. $0.1 \%$ ascorbic acid was used as conservative (Hagerman 1987). For total tannins, we used the radial diffusion method with agarose gel added with bovine serum albumine (Hagerman 1987). We punched 8 wells in each plate. Each sample was resuspended in 
$200 \mu \mathrm{l}$ of $70 \%$ acetone and $50 \mu \mathrm{l}$ of each sample was placed in the wells. The plates were covered and placed in an incubator at $30{ }^{\circ} \mathrm{C}$ for $96 \mathrm{~h}$. We used a digital Vernier to estimate the diameter of the ring that formed. The area of the disk is linearly related to the amount of tannins placed in the well. To quantify gallotannins, a modification of the method by Inoue and Hagerman (1988) was used. One $\mathrm{ml}$ of the samples resuspended in $0.2 \mathrm{~N} \mathrm{H}_{2} \mathrm{SO}_{4}$ were placed in a $2 \mathrm{ml}$ tube and dissolved in $1 \mathrm{ml} 1 \mathrm{M} \mathrm{H}_{2} \mathrm{SO}_{4}$. The samples were hydrolyzed for $4 \mathrm{~h}$ at $100{ }^{\circ} \mathrm{C}$. A $0.1 \mathrm{ml}$ aliquot of the hydrolysate was mixed with $0.3 \mathrm{ml}$ of $0.667 \%$ methanolic rhodanine solution and $0.2 \mathrm{ml}$ of $0.5 \mathrm{M} \mathrm{KOH}$ solution. After $2.5 \mathrm{~min}$, the mixture was diluted to $5 \mathrm{ml}$ with distilled water. The absorbance at $520 \mathrm{~nm}$ was read. The rhodanine assay was standardized with gallic acid. Soluble proanthocyanidins (PAS) were measured using a modification of the method of Watterson and Butler (1983). Samples were resuspended in $50 \%$ methanol. $0.1 \mathrm{ml}$ of extract and $0.6 \mathrm{ml}$ of water were added to $6 \mathrm{ml} \mathrm{1-butanol} /$ concentrated $\mathrm{HCl}(95: 5, \mathrm{v} / \mathrm{v})$. After mixing, the tubes were placed in a bath for $50 \mathrm{~min}$ at $95{ }^{\circ} \mathrm{C}$. The absorbance at $555 \mathrm{~nm}$ was measured. The standard curve was prepared with known concentrations of $(+)$ catechin hydrate. Finally, to quantify hydrolyzable tannins the dry samples were placed into Pyrex screw top tubes. Two $\mathrm{ml}$ of methanol and $200 \mu \mathrm{l}$ of concentrated sulfuric acid $(18 \mathrm{M})$ were added. The samples were hydrolyzed for $20 \mathrm{~h}$ at $85^{\circ} \mathrm{C} .50 \mu \mathrm{l}$ aliquots of ethanolamine were added. Five hundred $\mu \mathrm{l}$ of $3.7 \mathrm{M}$ ammonium acetate was added before the $\mathrm{pH}$ was adjusted to 5.5. Each sample was stored at $4{ }^{\circ} \mathrm{C}$. One hundred $\mu \mathrm{l}$ of the samples with adjusted $\mathrm{pH}$, were analyzed by reaction with $\mathrm{KIO}_{3}$ at $525 \mathrm{~nm}$. The method is standardized with methyl gallate (Hartzfeld et al. 2002).

\section{Statistical analysis}

To estimate genetic diversity in each of the four studied populations, we calculated the average number of alleles per locus $\left(N_{\mathrm{A}}\right)$, the average effective number of alleles per locus $\left(N_{\mathrm{E}}\right)$, the observed heterozygosity $\left(H_{\mathrm{O}}\right)$ and the expected heterozygosity $\left(H_{\mathrm{E}}\right)$ with the software GenAlex v. 6.501 (Peakall and Smouse 2006). Microsatellite data were also used to estimate three measures of individual genetic variation for each tree, uncorrected homozygosity, homozygosity by locus and internal relatedness, using the CERNICALIN software (Aparicio et al. 2006). However, the three measures were highly correlated $(r>0.98)$ and therefore we only report individual observed heterozygosity (calculated as 1-uncorrected homozygosity) as a measure of genetic variation. Nested analyses of variance were conducted to test the effect of forest condition (i.e. small vs. large patches) and site (nested within forest condition), on individual heterozygosity, herbivory levels by folivores and leaf miners and on the contents of water, total nonstructural carbohy- drates and secondary metabolites. Correlation analyses were used to test if variation in herbivory levels by both insect guilds is associated with the foliar content of water, nonstructural carbohydrates and secondary metabolites.

To determine if similar genotypes of $Q$. castanea have similar contents of nutritional and chemical compounds and levels of herbivory, we calculated a pairwise distance matrix for each data set. For the genetic data, a matrix of codominat-genotypic distance was calculated using GeneAlex v. 6.501 (Peakall and Smouse 2006). For foliar chemistry and herbivory damage Euclidean distances were calculated with the NTSYSpc 2.2 program (Rohlf 2002). Separate matrices were obtained for damage by folivores and miners. Matrices were subjected to a Principal Coordinates Analysis (PcoA), and individual score values on the first two coordinates were graphed to depict similarity patterns (Orloci 1978; Peakall and Smouse 2006). Correlations among matrices were determined with simple and partial Mantel permutation tests (Mantel 1967) in NTSYSpc.

\section{Results}

The highest levels of genetic variation were observed in population SAU (small fragment), followed by population CUA (large fragment), while populations SMM (small fragment) and UME (large) had comparatively lower genetic variation by all measures (Table 1). The nested ANOVAs indicated that forest condition (small $v s$. large fragments) did not have a significant effect on the genetic diversity levels (individual heterozygosity) of oak individuals in the studied sites $(F=1.23$, d. f. $=1$, $P=0.27$ ) (Fig. 1). On the contrary, there was a significant effect of forest condition on levels of herbivory by folivores $(F=26.49$, d. f. $=1, P<0.0001)$ and leaf miners $(F=19.76$, d. f. $=1, P=0.0002)$ (Fig. 2$)$ and on the percentage of leaf water and concentration of hydrolysable tannins (Table 2). Herbivory levels by folivores were higher in the small (mean \pm standard error $=9.88 \pm 0.99 \%$ ) than in the large fragments $(4.36 \pm 0.47 \%)$, and the opposite was true for herbivory by leaf miners $(1.13 \pm 0.21$ and $2.52 \pm 0.53 \%$, respectively) (Fig. 2).

Independently of forest condition, the effect of site was significant for individual observed heterozygosity $(F=10.61$, d. f. $=2, P=0.0002)$ (Fig. 1) the levels of herbivory by leaf miners $(F=37.13$, d. f. $=2$, $P<0.0001$ ) (Fig. 2), the percentage of leaf water, and the concentrations of total nonstructural carbohydrates, flavonoids, gallotannins, soluble proanthocyanidins and hydrolysable tannins (Table 2). Except for the case of flavonoids, the concentration of all these compounds followed a similar pattern in which the higher concentrations was observed in sites UME and SMM, and the lower concentrations in sites SAU and CUA. Finally, no significant variation was observed for the concentration of total phenols and total tannins. 
Table 1 Genetic diversity parameters for the four studied populations of $Q$. castanea that occur in small (San Miguel del Monte, SMM and Santiago Undameo, SAU) and large (Umécuaro, UME and Cuanajo, CUA) forest fragments

\begin{tabular}{|c|c|c|c|c|}
\hline Population & $N_{\mathrm{A}}$ & $N_{\mathrm{E}}$ & $H_{\mathrm{O}}$ & $H_{\mathrm{E}}$ \\
\hline \multicolumn{5}{|c|}{ Small fragments } \\
\hline SMM & $8.3(1.36)$ & $5.7(1.66)$ & $0.73(0.08)$ & $0.73(0.07)$ \\
\hline SAU & $10.0(0.97)$ & $7.7(0.72)$ & $0.93(0.04)$ & $0.86(0.01)$ \\
\hline \multicolumn{5}{|c|}{ Large fragments } \\
\hline UME & $7.0(1.26)$ & $4.7(1.18)$ & $0.66(0.10)$ & $0.69(0.09)$ \\
\hline CUA & $9.5(0.92)$ & $6.7(0.99)$ & $0.89(0.06)$ & $0.83(0.02)$ \\
\hline
\end{tabular}

Standard errors are shown in parenthesis

$N_{A}$ mean number of alleles per locus, $N_{E}$ mean number of effective alleles per locus, $H_{O}$ observed heterozygosity, $H_{E}$ expected heterozygosity

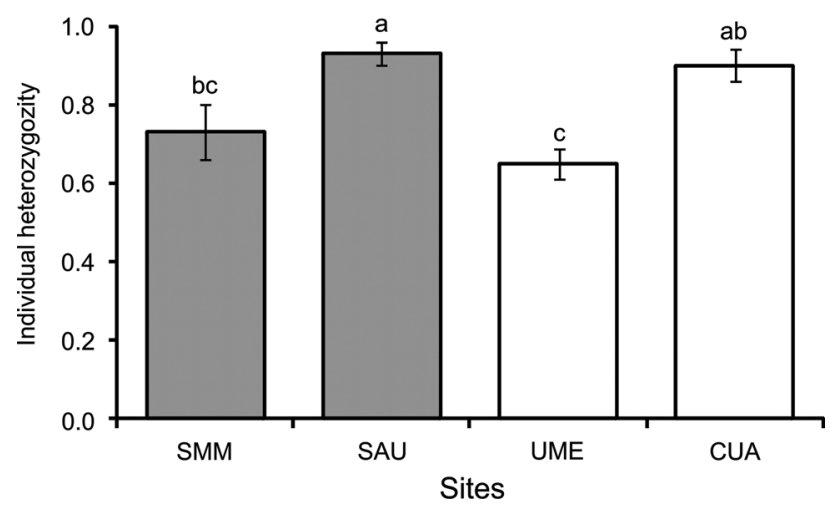

Fig. 1 Individual observed heterozygosity (Mean $\pm \mathrm{SE}$ ) of Quercus castanea individuals at small (San Miguel del Monte, SMM and Santiago Undameo, SUA; gray bars) and large (Umécuaro, UME and Cuanajo, CUA; white bars) forest fragments. Different letters indicate significant differences $(P<0.05)$ according to ANOVA followed by post hoc Tukey-Kramer tests

After a Bonferroni correction, correlation analyses indicated that the percentage of leaf area damaged by folivores was associated significantly (and negatively) only with the percentage of leaf water (Table 3). In contrast, the level of herbivory by leaf miners was negatively associated with the concentration of gallotannins, soluble proanthocyanidins, hydrolysable tannins and total nonstructural carbohydrates, and positively associated with the concentration of flavonoids (Table 3).

The principal coordinates analyses based on pairwise genetic distances and on chemical distances among all individuals (Fig. 3a, b) were largely congruent in recognizing two main groups of individuals, one formed by individuals from populations UME and SMM, and the other by individuals from populations CUA and SAU. In contrast, when the level of damage by folivorous insects was used as the input variable, a different pattern is observed (Fig. 3c). All individuals from SMM, together with four individuals from SAU, and one individual from CUA distributed on the left side of the plot, reflecting the higher herbivory levels of these individuals. The rest of the individuals, characterized by lower herbivory levels, distributed on the right side of the plot. The pattern for the levels of damage by miners (Fig. 3d) indicated the separation of individuals from CUA and a few individuals from SMM and SAU, with high damage levels, from the rest of the individuals.

Mantel correlation tests indicated a significant correlation between the matrices of genetic and chemical distance $(r=0.29 ; P=0.001)$ (Fig. 4a, b). The correlation increased considerably when the matrix of chemical distances was calculated including only carbohydrates, gallotannins, hydrolysable tannins and proanthocyanidins (chemical distance 2; $r=0.41$; $P=0.001$ ) (Fig. 4c, d). Another significant correlation was found between chemical distance and the distance based on damage by mining insects $(r=0.51$; $P=0.002$ ) (Fig. 4b), but the correlation was lower with chemical distance $2(r=0.21 ; P=0.005)$ (Fig. 4d). Even within one of the sites (UME), a significant correlation was found between the matrix of chemical distance and the matrix of damage by mining insects $(r=0.48 ; P=0.03)$ (not shown), and the correlation between the matrices of genetic and chemical distances was marginally significant $(r=0.3 ; P=0.07$ ) (not shown). In contrast, no correlations were found between any of the two chemical distances and damage levels by folivorous insects (Fig. 4a, c), and between genetic distance and damage levels by folivores $(r=-0.02$, $P=0.43) \quad$ (Fig. 4a) and leaf miners $(r=0.06$, $P=0.24$ ) (Fig. 4b). Very similar results were obtained when correlations were partialized between two matrices while controlling for the third one (Fig. 4).

\section{Discussion}

The results of this study indicate significant variation in genetic diversity, damage levels by insect folivores and leaf miners and in the concentration of nutritional and secondary chemistry compounds among the four $Q$. castanea populations studied. However, the results regarding the effects of forest condition on the variables evaluated must be taken with caution since only two sites of each type (i.e. small and large forest fragments) were analyzed.

As has been commonly found even in highly fragmented oak populations (e.g. Ortego et al. 2010), genetic 
diversity was high in the four studied populations and was not associated with forest condition. This result is probably due to several factors, including the long generation time of Quercus species, what makes it difficult to observe the effects of recent (i.e. a few decades) fragmentation on population genetic diversity levels of adult individuals (Ortego et al. 2010; Herrera-Arroyo et al. 2013).

Damage by insect folivores was significantly higher in the two small and fragmented forest patches populations of $Q$. castanea than in the large forest patches. It is

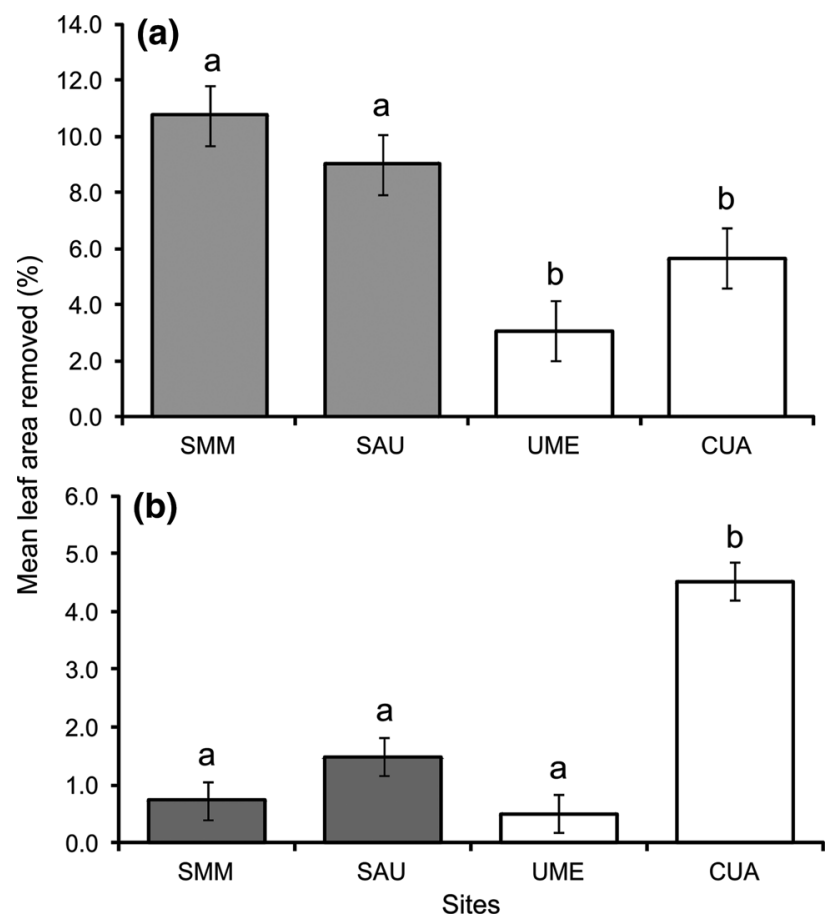

Fig. 2 Percentage leaf area removed (Mean \pm SE) in Quercus castanea individuals at small (San Miguel del Monte, SMM and Santiago Undameo, SAU; gray bars) and large (Umécuaro, UME and Cuanajo, CUA; white bars) forest fragments by a folivores and b leaf mining insects. Different letters indicate significant differences $(P<0.05)$ according to ANOVA followed by post hoc TukeyKramer tests known that habitat fragmentation modifies local microclimatic conditions (Camargo and Kapos 1995), plant diversity and composition (Benítez-Malvido and Martínez-Ramos 2003), population density and dynamics (Wiegand et al. 2005), and destabilizes and collapses interspecific interactions such as pollination, parasitism and predation (Stouffer and Bierregaard 1995; Kearns et al. 1998; Fagan et al. 1999; Arnold and Asquith 2002). Some studies have also documented increased herbivory levels in fragmented and disturbed habitats, probably due to the above-mentioned factors and to changes in plant nutritional quality and concentration of defensive compounds, and also to a reduction in the abundance of predators and parasitoids (Krues and Tscharntke, 1994; Arnold and Asquith 2002; Fáveri et al. 2008; Cuevas-Reyes et al. 2013). In our case, we found significant but not very considerable differences in water and hydrolysable tannins concentration among trees in the two types of forest fragments, and herbivory levels were correlated with the percentage of leaf water, but not with the concentration of secondary metabolites or total nonstructural carbohydrates. This suggests that differential folivory in our study system might be related to other chemical or ecological factors not assessed in this study.

In contrast, herbivory by leaf-mining insects was lower in the more disturbed sites and showed significant negative correlations with the concentration of gallotannins, soluble proanthocyanidins, hydrolysable tannins and total nonstructural carbohydrates. It has been suggested that leaf miners are more sensitive to the underlying genetic and chemical structure of the host plant because these insects interact directly with leaf tissue and must spend their entire larval stage on the individual host plant chosen by the ovipositing female (Bangert et al. 2006, 2008). Also, in general, the density of specialist herbivorous insects seems to be more likely to correlate negatively with the concentration of condensed tannins than generalist species (Forkner et al. 2004, but see Pearse 2011). This is perhaps because some free-living generalist insect herbivores have the capability of moving within or among host plants and, in this way, exert control over their degree of exposition to

Table 2 Differences in foliar nutritional and secondary compounds among individuals of $Q$. castanea in the four studied populations

\begin{tabular}{|c|c|c|c|c|c|c|}
\hline \multirow[t]{2}{*}{ Chemical compound } & \multicolumn{2}{|c|}{ Small fragments } & \multicolumn{2}{|c|}{ Large fragments } & \multirow[t]{2}{*}{ Condition $F($ d. f. $=1)$} & \multirow[t]{2}{*}{ Site $F($ d. f. $=2)$} \\
\hline & SMM & SAU & UME & CUA & & \\
\hline Water $(\%)$ & $37.5 \pm 2.95$ & $59.8 \pm 1.50$ & $68.1 \pm 1.45$ & $48.6 \pm 3.17$ & $16.28 * * *$ & $37.92 * * *$ \\
\hline $\mathrm{TNC}\left(\mathrm{mg} \mathrm{g}^{-1}\right)$ & $18.5 \pm 0.37$ & $9.9 \pm 0.06$ & $19.4 \pm 0.93$ & $10.5 \pm 0.82$ & $1.50 \mathrm{n.s.}$ & $90.20 * * *$ \\
\hline Total phenols $\left(\mathrm{mg} \mathrm{g}^{-1}\right)$ & $6.6 \pm 0.30$ & $6.0 \pm 0.25$ & $6.12 \pm 0.30$ & $7.2 \pm 0.85$ & 0.48 n. s. & $1.61 \mathrm{n} . \mathrm{s}$. \\
\hline Flavonoids $\left(\mathrm{mg} \mathrm{g}^{-\mathrm{P}}\right)$ & $1.2 \pm 0.03$ & $0.92 \pm 0.02$ & $0.92 \pm 0.02$ & $1.5 \pm 0.29$ & 1.19 n. s. & $4.15^{*}$ \\
\hline Gallotannins $\left(\mathrm{mg} \mathrm{g}^{-1}\right)$ & $3.0 \pm 0.09$ & $0.05 \pm 0.01$ & $3.4 \pm 0.28$ & $0.08 \pm 0.01$ & 2.24 n. s. & $232.91 * * *$ \\
\hline PAS $\left(\mathrm{mg} \mathrm{g}^{-1}\right)$ & $6.2 \pm 0.45$ & $2.3 \pm 0.02$ & $6.7 \pm 0.27$ & $2.0 \pm 0.12$ & 0.06 n. s. & $127.56^{* * *}$ \\
\hline $\mathrm{HT}\left(\mathrm{mg} \mathrm{g}^{-1}\right)$ & $14.8 \pm 0.45$ & $0.21 \pm 0.1$ & $17.1 \pm 0.92$ & $0.11 \pm 0.03$ & $4.76^{*}$ & $476.50 * * *$ \\
\hline Total tannins $\left(\mathrm{mg} \mathrm{g}^{-1}\right)$ & $22.4 \pm 5.17$ & $9.6 \pm 1.0$ & $10.4 \pm 1.15$ & $11.8 \pm 5.60$ & $1.58 \mathrm{n} . \mathrm{s}$. & 2.76 n. s. \\
\hline
\end{tabular}

See Table 1 for population abbreviations. TNC total nonstructural carbohydrates, $P A S$ proanthocyanidins, HT hydrolyzable tannins, $n$. $s$. non significant

$* P<0.05, * * * P<0.001$ 
Table 3 Pairwise correlations among herbivory levels by folivores and miners, and the concentrations of foliar nutritional and secondary compounds in Quercus castanea

\begin{tabular}{|c|c|c|c|c|c|c|c|c|c|c|}
\hline & Folivores & Miners & Water & TNC & $\mathrm{TP}$ & FLA & GALLO & PAS & HT & TT \\
\hline \multicolumn{11}{|l|}{ Folivores } \\
\hline Miners & -0.02 & & & & & & & & & \\
\hline Water & -0.51 & -0.28 & & & & & & & & \\
\hline TNC & -0.11 & -0.51 & -0.05 & & & & & & & \\
\hline $\mathrm{TP}$ & -0.01 & 0.43 & -0.26 & -0.01 & & & & & & \\
\hline FLA & -0.03 & 0.57 & -0.38 & -0.02 & 0.85 & & & & & \\
\hline GALLO & -0.08 & -0.57 & -0.01 & 0.83 & -0.03 & -0.16 & & & & \\
\hline PAS & -0.08 & -0.63 & -0.02 & 0.79 & -0.08 & -0.19 & 0.93 & & & \\
\hline HT & -0.12 & -0.63 & 0.06 & 0.93 & -0.11 & -0.18 & 0.92 & 0.88 & & \\
\hline $\mathrm{TT}$ & 0.29 & -0.15 & -0.31 & 0.09 & 0.03 & -0.01 & 0.21 & 0.19 & 0.19 & \\
\hline
\end{tabular}

Values in bold are significant after a Bonferroni correction

$T N C$ total nonstructural carbohydrates, TP total phenols, FLA flavonoids, GALLO gallotannins, $P A S$, proanthocyanidins, $H T$ hydrolyzable tannins, $T T$ total tannins
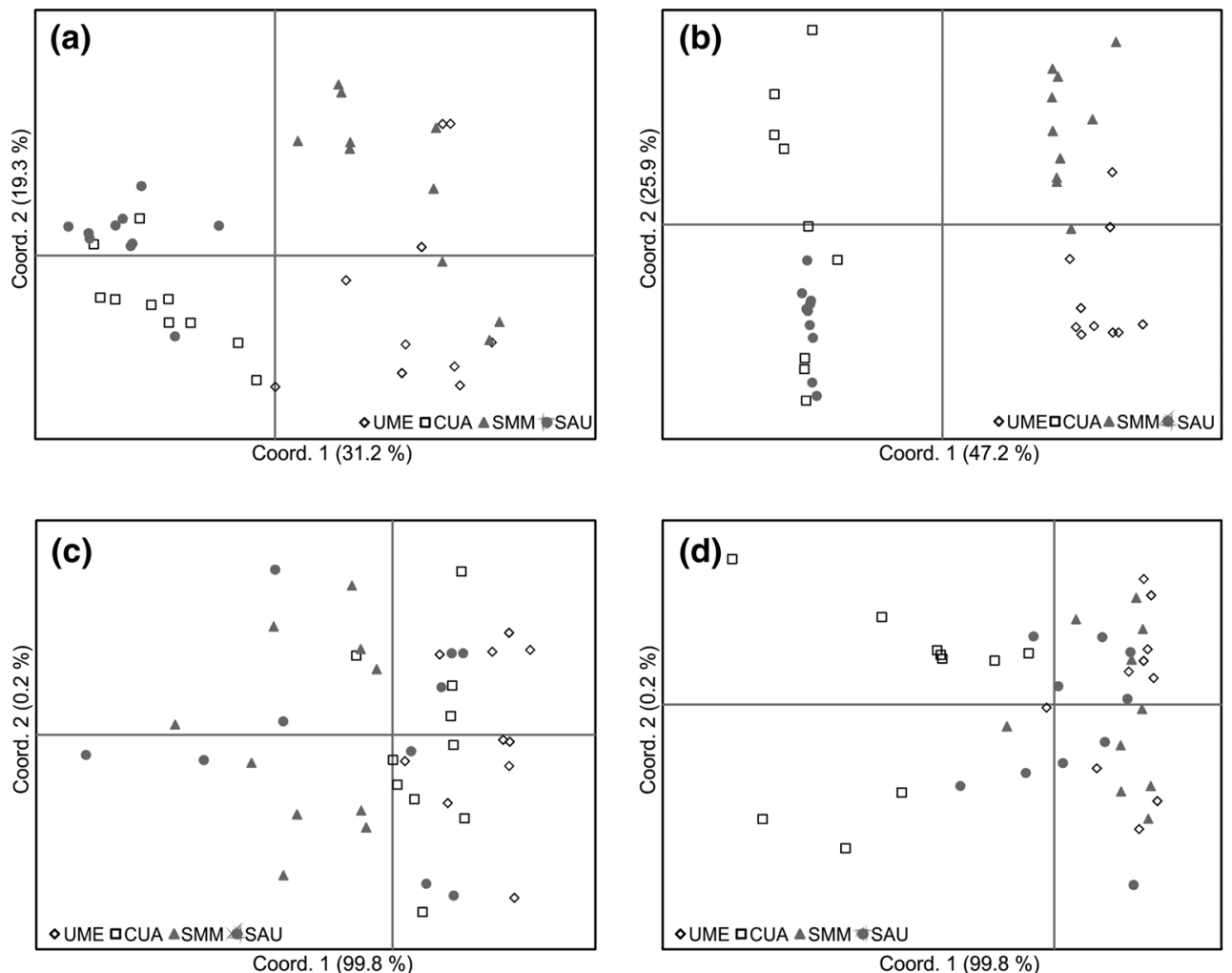

Fig. 3 Principal Coordinates Analysis depicting similarity relationships among individuals of sampled populations based on a genetic distance, $\mathbf{b}$ chemical distance, $\mathbf{c}$ herbivory levels by folivores and $\mathbf{d}$ herbivory levels by leaf miners. In each case the percentage of the total variation explained by each axis is indicated in parenthesis

different secondary metabolites. However, these insects may be at the same time more susceptible to external conditions such as humidity, temperature and light.

We observed significant differences among the four sites in the percentage of leaf water, and in the concentration of carbohydrates, flavonoids, soluble proanthocyanidins, gallotannins and hydrolysable tannins. The last two compound types showed the more marked differences, with sites SMM and UME having high concentration, and sites SAU and CUA low concen- tration. While the concentration of tannins in plants is known to vary according to ontogenetic state, tissue type, and environmental conditions including $\mathrm{CO}_{2}$ concentration, soil nutrient availability, light conditions, and herbivore attack (Lindroth et al. 1993, 1997; Mansfield et al. 1999; Liu et al. 2005), it has also been shown that there is high genetically controlled intraspecific variation in tannin concentration in many different plant species, including Quercus, that can be sometimes as considerable as a 145 fold difference 


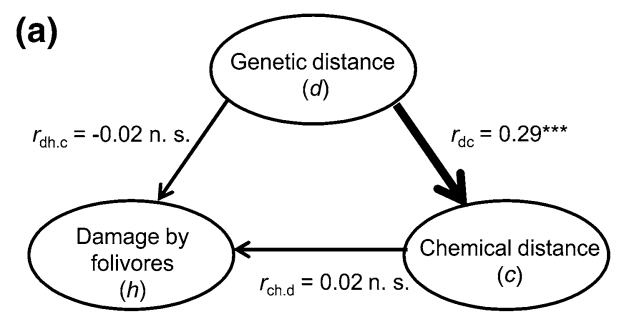

(c)

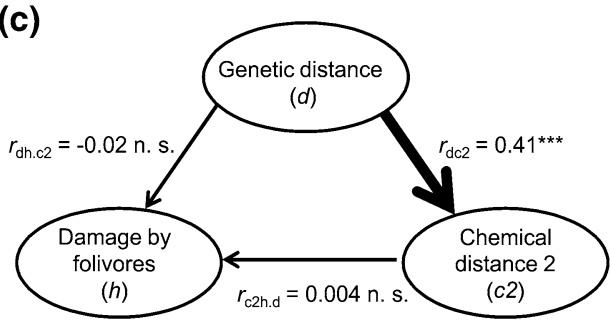

Fig. 4 Mantel test results for simple $\left(r_{x y}\right.$ where $x$ is the predictor and $y$ is the response) and partial ( $r_{x y . z}$ where $x$ is the predictor, $y$ the response and $z$ is the covariate whose effect on $\mathrm{x}$ and $\mathrm{y}$ is accounted for) correlations for a genetic distance $(d)$, chemical distance $(c)$ and herbivory levels by folivores $(h)$, b genetic distance $(d)$, chemical distance $(c)$ and herbivory levels by leaf miners $(m)$,

(Dungey et al. 2000; Dalzell and Shelton 2002; Madritch and Hunter 2002; O'Reilly-Wapastra et al. 2005; Osier and Lindroth 2006; Rehill et al. 2006).

Our microsatellite data supports the idea that the variation in the concentration of secondary metabolites that we observed within and among populations of $Q$. castanea has a genetic component. A Principal Coordinates Analysis based on chemical similitude among individuals resulted in a grouping pattern that was similar to the grouping of individuals based on six nuclear microsatellite loci. Also, a Mantel test between both pairwise matrices indicated a significant correlation. Particularly, carbohydrates, gallotannins, hydrolysable tannins and proanthocyanidins seemed to correlate more strongly with genetics than the other compounds. Previously, some other studies have also identified a correlation between genetic relatedness among individual trees, as measured with nuclear microsatellites, and the concentration of foliar chemical compounds, particularly in Quercus laevis (Klaper et al. 2001) and Eucalyptus melliodora (Andrew et al. 2005). In Populus, an important series of studies has demonstrated that in hybrid systems, as well as within single pure species, individuals with lower genetic distances have a more similar chemical composition and also support similar arthropod communities (Bailey et al. 2006; Bangert et al. 2006; Wimp et al. 2007; Bangert et al. 2008). According to the genetic similarity rule proposed by Bangert et al. (2006) the relationships between plant genetics and plant chemistry, and between plant chemistry and arthropod community structure, should be stronger than the direct relationship between plant genetics and arthropod community. Therefore, plant chemistry acts as the intermediate link between plant genes and the community of associated organisms.
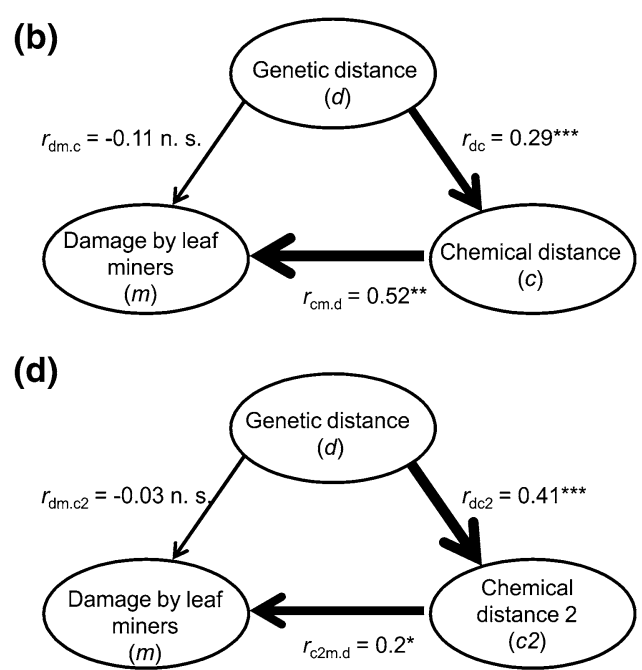

c genetic distance $(d)$, chemical distance 2 , calculated including only carbohydrates, gallotannins, hydrolysable tannins and proanthocyanidins $(c 2)$ and herbivory levels by folivores $(h)$ and $\mathbf{d}$ genetic distance $(d)$, chemical distance $2(c 2)$ and herbivory levels by leaf miners $(m)$. The width of each arrow is proportional to the strength of the relationship

Even though in our study we did not analyze the composition of the arthropod community associated to $Q$. castanea, but only considered damage levels by two insect guilds (folivores and leaf miners), altogether our results evidenced that the variation in the concentration of secondary metabolites among individuals of this oak species was associated with their genetic similarity across the study locations. Damage levels by one of the insect guilds (leaf miners) were correlated with the concentration of secondary metabolites. As can be expected from the genetic similarity rule, we did not detect a direct relationship between genetic composition of individual trees and damage by leaf miners (Fig. 4). In contrast, damage level by leaf chewing insects was not correlated with the genetic or chemical composition of $Q$. castanea individuals, but was higher in the small and more disturbed sites, and lower in the two larger fragments, even though this result should be taken with caution given the small sample size. This suggests that some insect guilds (i.e. specialist insects that interact intimately with the host) may be more sensitive to the genetic and chemical characteristics of individual plants, while more generalist free-living insects are probably more responsive to the variation in the environmental conditions of the habitat; in this case, variation caused by human disturbance.

Recently, it has been found that besides genetic similarity among host trees, differences in genetic diversity at the population level may be also related with herbivory levels. Using a manipulative experiment, Castagneyrol et al. (2012) found that damage by folivores in Quercus robur saplings increased with the number of genotypes in the experimental plots. However, no relationship was found between genetic diversity and damage by leaf miners. These examples illustrate that different responses of herbivorous insects to genetic 
diversity at both individual and population levels are possible and require further research.

Acknowledgments We thank J. M. Peñaloza-Ramírez for field assistance and V. Rocha, H. Rodríguez-Correa and A. Valencia for technical assistance. The comments by I. S. Pearse, H. Tomimatsu and an anonymous reviewer are greatly appreciated. This project was supported by CONACYT Grant No. 2008-105755 to P. Cuevas-Reyes.

\section{References}

Abrahamson WG, Hunter MD, Melika G, Price PW (2003) Cynipid gall-wasp communities correlate with oak chemistry. J Chem Ecol 29:209-223. 10.1890/1051-010.1023/A:1021993017237

Aguilar R, Quesada M, Ashworth L, Herrerías-Diego Y, Lobo J (2008) Genetic consequences of habitat fragmentation: susceptible signals in plant traits and methodological approaches. Mol Ecol 17:5177-5188. doi:10.1111/j.1365-294X.2008.03971.x

Aldrich PR, Michler CH, Sun W, Romero-Severson J (2002) Microsatellites markers for northern red oak (Fagaceae: Quercus rubra). Mol Ecol Notes 2:472-474. doi:10.1046/j.1471-8286. 2002.00282.x

Anderson SS, McCrea KD, Abrahamson WG, Hartzel LM (1989) Host genotype choice by the ball gall-maker Eurosta solidaginis (Diptera: Tephritidae). Ecology 70:301-306. doi:10.2307/1941373

Andrew RL, Peakall R, Wallis IR, Wood JT, Knight EJ, Foley WJ (2005) Marker-based quantitative genetics in the wild?: the heritability and genetic correlation of chemical defenses in Eucalyptus. Genetics 171:1989-1998. doi:10.1534/genetics.105. 042952

Aparicio JM, Ortego J, Cordero PJ (2006) What should we weigh to estimate heterozygosity, alleles or loci? Mol Ecol 15:4659-4665. doi:10.1111/j.1365-294X.2006.03111.x

Arnold AE, Asquith NM (2002) Herbivory in a fragmented tropical forest: patterns from islands at Lago Gatún, Panamá. Biodivers Conserv 11:1663-1680. doi:10.1023/A:1016888000369

Arredondo-León C, Muñoz-Jiménez J, García-Romero A (2008) Recent changes in landscape-dynamics trends in tropical highlands, central Mexico. Interciencia 33:569-577

Bailey JK, Wooley SC, Lindroth RL, Whitham TG (2006) Importance of species interactions to community heritability: a genetic basis to trophic-level interactions. Ecol Lett 9:78-85. doi:10.1111/j.1461-0248.2005.00844.x

Bangert RK, Turek RJ, Rehill B, Wimp GM, Schweitzer JA, Allan GJ, Bailey JK, Martinsen GD, Keim P, Lindroth RL, Whitham TG (2006) A genetic similarity rule determines arthropod community. Mol Ecol 15:1379-1391. doi:10.1111/j.1365-294X. 2005.02749.x

Bangert RK, Lonsdorf EV, Wimp GM, Shuster SM, Fischer D, Schweitzer JA, Allan GJ, Bailey JK, Whitham TG (2008) Genetic structure of a foundation species: scaling community phenotypes from the individual to the region. Heredity 100:121-131. doi:10.1038/sj.hdy.6800914

Barbour RC, O'Reilly-Wapstra JM, De Little DW, Jordan GJ, Steane DA, Humphreys JR, Bailey JK, Whitham TG, Potts DM (2009) A geographic mosaic of genetic variation within a foundation tree species and its community-level consequences. Ecology 90:1762-1772. doi:10.1890/08-0951.1

Bello M, Labat J (1987) Los encinos (Quercus) del estado de Michoacán, México. Cuaderno de Estudios Michoacanos 1. CEMCA-INIFAP-SARH, México

Benítez-Malvido J, Martínez-Ramos M (2003) Impact of forest fragmentation on understory plant species richness in Amazonia. Conserv Biol 17:389-400. doi:10.1046/j.1523-1739.2003.01120.x

Bocco G, Mendoza ME, Masera OR (2001) La dinámica del cambio de uso del suelo en Michoacán. Una propuesta metodológica para el estudio de los procesos de deforestación. Investigaciones Geográficas, Boletín del Instituto de Geografía, UNAM 44:18-38
Boecklen WJ, Spellenberg R (1990) Structure of herbivore communities in two oak (Quercus spp.) hybrid zones. Oecologia 85:92-100. doi:10.1007/BF00317348

Camargo JLC, Kapos V (1995) Complex edges effects on soil moisture and microclimate in central Amazonian forest. J Trop Ecol 11:205-221. doi:10.1017/S026646740000866X

Castagneyrol B, Lagache L, Giffard B, Kremer A, Jactel H (2012) Genetic diversity increases insect herbivory on oak saplings. PLoS One 7:e44247. doi:10.1371/journal.pone.0044247

Chust G, Garbin L, Pujade-Villar J (2007) Gall wasps and their parasitoids in cork oak fragmented forest. Ecol Entomol 32:82-91. doi:10.1111/j.1365-2311.2006.00850.x

Cronin JT, Abrahamson WG (2001) Goldenrod stem galler preference and performance: effects of multiple herbivores and plant genotypes. Oecologia 127:87-96. doi:10.1007/s004420000561

Crutsinger GM, Collins MD, Fordyce JA, Gompert Z, Nice CC, Sanders NJ (2006) Plant genotypic diversity predicts community structure and governs an ecosystem process. Science 313:966-968. doi:10.1126/science.1128326

Cuevas-Reyes P, Gilberti L, González-Rodríguez A, Fernandes GW (2013) Patterns of herbivory and fluctuating asymmetry in Solanum lycocarpum St. Hill (Solanaceae) along an urban gradient in Brazil. Ecol Indic 24:557-561. doi:10.1016/ j.ecolind.2012.08.011

Cunningham M, Moritz C (1998) Genetic effects of forest fragmentation on a rainforest restricted lizard (Scincidae: Gnypetoscincus queenslandiae). Biol Conserv 83:19-30. doi: 10.1016/S0006-3207(97)00046-3

Dalzell SA, Shelton SM (2002) Genotypic variation in proanthocyanidin status of Leucaena genus. J Agric Sci 138:209-220. doi: $10.1017 /$ S0021859601001848i

Donaldson JR, Lindroth RL (2007) Genetics, environment, and interactions determine efficacy of chemical defense in trembling aspen. Ecology 88:729-739. doi:10.1890/06-0064

Dungey HS, Potts BM, Whitham TG, Li H-L (2000) Plant genetics affects arthropod community richness and composition: evidence from a synthetic eucalypt hybrid population. Evolution 54:1938-1946. doi:10.1111/j.0014-3820.2000.tb01238.x

Erickson AA, Bell SS, Dawes CJ (2004) Does mangrove leaf chemistry help explain crab herbivory patterns? Biotropica 36:333-343. doi:10.1111/j.1744-7429.2004.tb00325.x

Faeth SH, Bultman TL (1986) Interacting effects of increased tannin levels on leaf-mining insects. Entomol Exp Appl 40:297-300. doi:10.1111/j.1570-7458.1986.tb00515.x

Fagan WE, Cantrell RS, Cosner DC (1999) How habitat edges change species interactions. Am Nat 153:165-182. doi:10.1086/303162

Fahring L (2003) Effects of habitat fragmentation on biodiversity. Annu Rev Ecol Evol Syst 34:487-515. doi:10.1146/ annurev.ecolsys.34.011802.132419

Fáveri SB, Vasconcelos HL, Dirzo R (2008) Effects of Amazonian forest fragmentation on the interaction between plants, insect herbivores, and their natural enemies. J Trop Ecol 24:57-64. doi:10.1017/S0266467407004592

Ferrusquía-Villafranca I (1993) Geology of Mexico: a synopsis. In: Ramammoorthy TP, Bye R, Lot A, Fa J (eds) Biological diversity of Mexico: origins and distribution. Oxford University Press, New York, pp 3-107

Floren A, Linsenmair KE (2001) The influence of anthropogenic disturbances on the structure of arboreal arthropod communities. Plant Ecol 153:153-167. doi:10.1023/A:1017510312462

Foggo A, Ozanne MRJ, Lill MR (2001) Edge effects and tropical forest canopy invertebrates. Plant Ecol 153:347-359. doi: 10.1023/A:1017594108769

Forkner RE, Marquis RJ, Lill JT (2004) Feeny revisited: condensed tannins as anti-herbivore defences in leaf-chewing herbivore communities of Quercus. Ecol Entomol 29:174-187. doi: 10.1111/j.1365-2311.2004.0590.x

Fritz RS, Price PW (1988) Genetic variation among plants and insect community structure: willows and sawflies. Ecology 69:845-856

Fritz RS, Simms EL (1992) Plant resistance to herbivores and pathogens: ecology, evolution and genetics. University of Chicago Press, Chicago 
Fritz RS, Nichols-Orians CM, Brunsfeld SJ (1994) Interspecific hybridization of plants and resistance to herbivores: hypotheses, genetics, and variable responses in a diverse community. Oecologia 97:106-117. doi:10.2307/1941034

Gerlach G, Musolf K (2000) Fragmentation of landscape as a cause for genetic subdivision in bank voles. Conserv Biol 14:1066-1074. doi:10.1046/j.1523-1739.2000.98519.x

Gibbs JP, Stanton EJ (2001) Habitat fragmentation and arthropod community change: carrion beetles, phoretic mites, and flies. Ecol Appl 11:79-85. doi:10.1890/1051-0761(2001)011[0079: HFAACC $] 2.0 . \mathrm{CO} ; 2$

Hagerman AE (1987) Radial diffusion method for determining tannin in plant extracts. J Chem Ecol 13:437-449. doi: 10.1007/BF01880091

Hambäck PA, Agren J, Ericson L (2000) Associational resistance: insect damage to purple loosestrife reduced in thickets of sweet gale. Ecology 81:1784-1794. doi:10.1890/00129658(2000)081[1784:ARIDTP]2.0.CO;2

Hartzfeld PW, Forkner R, Hunter MD, Hagerman AE (2002) Determination of hydrolyzable tannins (gallotannins and ellagitannins) after reaction with potassium iodate. J Agric Food Chem 50:1785-1790. doi:10.1021/jf0111155

Herrera-Arroyo L, Sork VL, González-Rodríguez A, RochaRamírez V, Vega E, Oyama K (2013) Seed-mediated connectivity among fragmented populations of Quercus castanea (Fagaceae) in a Mexican landscape. Am J Bot 100:1663-1671. doi:10.3732/ajb.1200396

Hinsley SA, Bellamy PE, Newton I, Sparks TH (1995) Habitat and landscape factors influencing the presence of individual breeding species in woodland fragments. J Avian Biol 26:94-104

Hochwender CG, Fritz RS (2004) Plant genetic differences influence herbivore community structure: evidence from a hybrid willow system. Oecologia 138:547-557. doi:10.1007/s00442-003-1472-4

Hughes AR, Inouye BD, Johnson MTJ, Underwood N, Vellend M (2008) Ecological consequences of genetic diversity. Ecol Lett 11:609-623. doi:10.1111/j.1461-0248.2008.01179.x

Hunter MD, Schultz JC (1995) Fertilization mitigates chemical induction and herbivore responses within damaged oak trees. Ecology 76:1226-1232. doi:10.2307/1940929

Hwang S-Y, Lindroth RL (1997) Clonal variation in foliar chemistry of aspen: effects on gypsy moths and forest tent caterpillars. Oecologia 111:99-108. doi:10.1007/s004420050213

Inoue KH, Hagerman AE (1988) Determination of gallotannin with rhodanine. Anal Biochem 169:363-369

Johnson MT, Agrawal AA (2005) Plant genotype and the environment interact to shape a diverse arthropod community on evening primrose (Oenothera biennis). Ecology 86:874-885. doi: 10.1890/04-1068

Johnson MTJ, Lajeunesse MJ, Agrawal AA (2006) Additive and interactive effects of plant genotypic diversity on arthropod communities and plant fitness. Ecol Lett 9:24-34. doi: 10.1111/j.1461-0248.2005.00833.x

Karban R (1992) Plant variation: its effects on populations of herbivorous insects. In: Fritz RS, Simms EL (eds) Plant resistance to herbivores and pathogens: ecology, evolution, and genetics. The University of Chicago Press, Chicago, pp 195-215

Kearns CA, Inouye DW, Waser NM (1998) Endangered mutualisms: the conservation of plant-pollinator interactions. Annu Rev Ecol Syst 29:83-112. doi:10.1146/annurev.ecolsys.29.1.83

Klaper R, Ritland K, Mousseau TA, Hunter MD (2001) Heritability of phenolics in Quercus laevis inferred using molecular markers. J Hered 92:421-426. doi:10.1093/jhered/92.5.421

Kolb A (2008) Habitat fragmentation reduces plant fitness by disturbing pollination and modifying response to herbivory. Biol Conserv 141:2540-2549. doi:10.1016/j.biocon.2008.07.015

Krues A, Tscharntke T (1994) Habitat fragmentation, species loss, and biological control. Science 264:1581-1584. doi: 10.1126/science. 264.5165 .1581

Lefort F, Douglas GC (1999) An efficient micro-method of DNA isolation from mature leaves of four hardwood tree species Acer, Fraxinus, Prunus and Quercus. Ann For Sci 56:259-263. doi:10.1051/forest:19990308
Lindroth RL, Kinney KK, Platz CL (1993) Responses of deciduous trees to elevated atmospheric $\mathrm{CO}_{2}$ : productivity, phytochemestry and insect performance. Ecology 74:763-777. doi:10.2307/1940804

Lindroth RL, Roth S, Kruger EL, Volin JC, Koss PA (1997) $\mathrm{CO}_{2^{-}}$ mediated changes in aspen chemistry: effects of gypsy moth performance and susceptibility to virus. Glob Chang Biol 3:279-289. doi:10.1046/j.1365-2486.1997.00077.x

Liu L, King JS, Giardina CP (2005) Effects of elevated concentrations of atmospheric $\mathrm{CO}_{2}$ and tropospheric $\mathrm{O}_{3}$ on leaf litter production and chemistry in trembling aspen and paper birch communities. Tree Physiol 25:1511-1522. doi:10.1093/treephys/25.12.1511

López E, Bocco G, Mendoza M, Aguirre JR (2006) Peasant emigration and land use change at the watershed level: a GIS-based approach in Central Mexico. Agric Syst 90:62-78. doi: 10.1016/j.agsy.2005.11.001

Maddox GD, Root RB (1990) Structure of the encounter between goldenrod (Solidago altissima) and its diverse insect fauna. Ecology 71:2115-2124. doi:10.2307/1938625

Madritch MD, Hunter MD (2002) Phenotypic diversity influences ecosystem functioning in an oak sandhills community. Ecology 83:2084-2090. doi:10.1890/0012-9658(2002)083[2084:PDIEFI]2.0.CO;2

Mansfield JL, Curtis PS, Zak DR, Pregitzer KS (1999) Genotypic variation for condensed tannin production in trembling aspen (Populus tremuloides, Salicaceae) under elevated $\mathrm{CO}_{2}$ and in high- and low-fertility soil. Am J Bot 86:1154-1159

Mantel N (1967) The detection of disease clustering and a generalized regression approach. Cancer Res 27:209-220

Marquis RJ, Newell EA, Villegas AC (1997) Nonstructural carbohydrates accumulation and use in understory rain forest shrub and relevance for the impact of leaf herbivory. Funct Ecol 5:636-643. doi:10.1046/j.1365-2435.1997.00139.x

McCrea KD, Abrahamson WG (1987) Variation in herbivore infestations: historical vs. genetic factors. Ecology 68:822-827. doi: $10.2307 / 1938353$

Mendoza EM, López EG, Geneletti D, Pérez-Salicrup DR, Salinas V (2011) Analysing land cover and land use changes processes at watershed level: a multitemporal study in the lake Cuitzeo wathershed, Mexico (1975-2003). Appl Geogr 31:237-250. doi: 10.1016/j.apgeog. 2010.05 .010

Nixon KC (1993) The genus Quercus in Mexico. In: Ramammoorthy TP, Bye R, Lot A, Fa J (eds) Biological diversity of Mexico: origins and distribution. Oxford University Press, New York, pp 447-458

O'Reilly-Wapastra JM, Potts BM, McArthur C, Davies NW, Tilyard P (2005) Inheritance of resistance to mammalian herbivores and of plant defensive chemistry in a Eucalytpus species. J Chem Ecol 31:357-375. doi:10.1007/s10886-005-1346-9

Orloci L (1978) Multivariate analysis in vegetation research. Dr W. Junk BV, The Hague

Ortego J, Bonal R, Muñoz A (2010) Genetic consequences of hábitat fragmentation in long-lived tree species: the case of the Mediterranean Holm Oak (Quercus ilex L.). J Hered 101:717-726. doi:10.1093/jhered/esq081

Osier TL, Lindroth RL (2006) Genotype and environment determine allocation to and costs of resistance in quaking aspen. Oecologia 148:293-303. doi:10.1007/s00442-006-0373-8

Peakall R, Smouse PE (2006) GENALEX 6: genetic analysis in excel. Population genetic software for teaching and research. Mol Ecol Notes 6:288-295. doi:10.1111/j.1471-8286.2005.01155.x

Pearse IS (2011) The role of leaf defensive traits in oaks on the preference and performance of a polyphagous herbivore, $\mathrm{Or}$ gyia vetusta. Ecol Entomol 36:635-642. doi:10.1111/j.13652311.2011.01308.x

Rehill BJ, Whitham TG, Martinsen GD, Schweitzer JA, Bailey JK, Lindroth RL (2006) Developmental trajectories in cottonwood phytochemistry. J Chem Ecol 32:2269-2285. doi:10.1007/ s10886-006-9141-9

Reusch TBH, Ehlers A, Hämmerli A, Worm B (2005) Ecosystem recovery after climatic extremes enhanced by genotypic diversity. Proc Natl Acad Sci USA 102:2826-2831. doi:10.1073/ pnas. 0500008102 
Rohlf FJ (2002) NTSYS-pc: numerical taxonomy system ver. 2.1. Exeter Publishing Ltd, New York

Rossiter MC, Schultz JC, Baldwin IT (1988) Relationships among defoliation, red oak phenolics, and gipsy moth growth and reproduction. Ecology 69:267-277. doi:10.2307/1943182

Schultz J, Baldwin IT (1982) Oak leaf quality declines in response to defoliation by gypsy moth larvae. Science $217: 149-151$. doi: 10.1126/science. 217.4555 .149

Sodhi NS, Lee TM, Koh LP, Brook BW (2009) A meta-analysis of the impact of anthropogenic forest disturbance on southeast Asia's biotas. Biotropica 41:103-109. doi:10.1111/ j.1744-7429.2008.00460.x

Steffan-Dewenter I, Münzenberg U, Bürger C, Thies C, Tscharntke T (2002) Scale dependent effects of landscape structure on three pollinator guilds. Ecology 83:1421-1432. doi:10.1890/00129658(2002)083[1421:SDEOLC]2.0.CO;2

Stouffer PC, Bierregaard RO (1995) Use of Amazonian forest fragments by understory insectivorous birds. Ecology 76:2429-2445. doi: $10.2307 / 2265818$

Templeton AR, Shaw K, Routman E, Davis SK (1990) The genetic consequences of habitat fragmentation. Ann Mo Bot Gard 77:13-27. doi:10.2307/2399621

Torres AM, Mau-Lastovicka T, Rezaaiyan R (1987) Total phenolics and high-performance liquid chromatography of phenolic acids of avocado. J Agric Food Chem 35:921-925. doi: $10.1021 /$ jf00078a018

Tovar-Sánchez E, Oyama K (2006) Effect of hybridization of the Quercus crassifolia $\times$ Quercus crassipes complex on the community structure of endophagous insects. Oecologia 147:702-713. doi:10.1007/s00442-005-0328-5

Tovar-Sánchez E, Valencia-Cuevas L, Castillo-Mendoza E, Mussali-Galante P, Pérez-Ruiz RV, Mendoza A (2013) Association between individual genetic diversity of two oak host species and canopy arthropod community structure. Eur J For Res 132:165-179. doi:10.1007/s10342-012-0665-y

Tscharntke T, Brandl R (2004) Plant-insect interactions in fragmented landscapes. Annu Rev Entomol 49:405-430. doi: 10.1146/annurev.ento.49.061802.123339

Valencia AS (1995) Contribución al conocimiento del género Quercus (Fagaceae) en el estado de Guerrero, México. Contribuciones del Herbario de la Facultad de Ciencias No. 1. Universidad Nacional Autónoma de México, México

Valencia-Ávalos S, Nixon KC (2004) Encinos. In: García-Mendoza AJ, Ordóñez MJ, Briones-Salas M (eds) Biodiversidad de Oaxaca. Instituto de Biología, UNAM-Fondo Oaxaqueño para la Conservación de la Naturaleza-World Wildlife Fund, México

Valladares G, Dalvo AR, Cagnolo L (2006) Habitat fragmentation effects on trophic processes of insect-plant food webs. Conserv Biol 20:212-217. doi:10.1111/j.1523-1739.2006.00337.x
Vásquez AA, Grez AA, Bustamante RO, Simonetti JA (2007) Herbivory, foliar survival and shoot growth in fragmented populations of Aristotelia chilensis. Acta Oecol 31:48-53. doi: 10.1016/j.actao.2006.03.006

Via S (1990) Ecological genetics and host adaptation in herbivorous insects: the experimental study of evolution in natural and agricultural systems. Annu Rev Entomol 35:421-446. doi: 10.1146/annurev.en.35.010190.002225

Watterson JJ, Butler LG (1983) Occurrence of an unusual leucoanthocyanidin and absence of proanthocyanidins in sorghum leaves. J Agric Food Chem 31:41-45. doi:10.1021/jf00115a011

Wettstein W, Schmid B (1999) Conservation of arthropod diversity in montane wetlands: effect of altitude, habitat quality and habitat fragmentation on butterflies and grasshoppers. J Appl Ecol 36:363-373. doi:10.1046/j.1365-2664.1999.00404.x

Whitham TG (1989) Plant hybrid zones as sinks for pests. Science 244:1490-1493. doi:10.1126/science. 244.4911.1490

Whitham TG, Martinsen GD, Floate KD, Dungey HS, Potts BM, Keim P (1999) Plant hybrid zones affect biodiversity: tools for a genetic based understanding of community structure. Ecology 80:416-428. doi:10.1890/00129658(1999)080[0416:PHZABT]2.0.$\mathrm{CO} ; 2$

Whitham TG, Young WP, Martinsen GD, Ghering CA, Schweitzer JA, Shuster SM, Wimp GM, Fischer DG, Bailey JK, Lindroth RL, Woolbright S, Kuske CR (2003) Community and ecosystem genetics: a consequence of the extended phenotype. Ecology 84:559-573. doi:10.1890/00129658(2003)084[0559:CAEGAC]2.0. $\mathrm{CO} ; 2$

Wiegand T, Revilla E, Moloney KA (2005) Effects of habitat loss and fragmentation on population dynamics. Conserv Biol 19:108-121. doi:10.1111/j.1523-1739.2005.00208.x

Wimp GM, Young WP, Woolbright SA (2004) Conserving plant genetic diversity for dependent animal communities. Ecol Lett 7:776-780. doi:10.1111/j.0014-3820.2005.tb00894.x

Wimp GM, Martinsen GD, Floate KD, Bangert RK, Whitham TG (2005) Plant genetic determinants of arthropod community structure and composition. Evolution 59:61-69. doi:10.1111/ j.1461-0248.2004.00635.x

Wimp GM, Wooley S, Bangert RK, Young WP, Martinsen GD, Keim P, Rehill B, Lindroth RL, Whitham TG (2007) Plant genetics predicts intra-annual variation in phytochemistry and arthropod community structure. Mol Ecol 16:5057-5069. doi: 10.1111/j.1365-294X.2007.03544.X

Zhuang XP, Lu YY, Yang GS (1992) Extraction and determination of flavonoids in ginkgo. Chin Herb Med 23:122-124 